\title{
A review of Drosera whittakeri s. lat. (Droseraceae) and description of a new species from Kangaroo Island, South Australia
}

\author{
Allen Lowrie ${ }^{1}$ and John G. Conran ${ }^{2}$ \\ ${ }^{1} 6$ Glenn Place, Duncraig, Western Australia 6023, Australia \\ ${ }^{2}$ Australian Centre for Evolutionary Biology and Biodiversity, Discipline of Ecology \& Evolutionary \\ Biology, DP 312, School of Earth and Environmental Sciences, The University of Adelaide, S.A. \\ 5005, Australia \\ Author for correspondence: john.conran@adelaide.edu.au
}

\begin{abstract}
A review of Drosera whittakeri s. lat. is presented, along with its more distant relative D. praefolia, and the case for recognition of the latter. Drosera whittakeri subsp. aberrans Lowrie \& Carlquist is raised to specific status as D. aberrans (Lowrie \& Carlquist) Lowrie \& Conran. As none of the original collections appear to have survived, a neotype is selected for D. whittakeri from close to Whittaker's original collection locality. A new Kangaroo Island endemic species, D. schmutzii Lowrie \& Conran, is described and illustrated. SEM micrographs of the seeds and a key to the four taxa are also provided.
\end{abstract}

\section{Introduction}

Drosera whittakeri Planch., as presently understood, is the only eastern Australian member of Drosera subgen. Ergaleium sect. Erythrorhiza (Lowrie 1987). This section is characterised by having tubers, a vertical, subterranean primary stem with prophylls; leaves rosulate, exstipulate, non-peltate, sessile or broadly petiolate; flowers sweetly scented; and styles 3 with many, divided, filiform segments (Marchant et al. 1982). In addition, replacement tubers show the unusual habit of developing inside the degenerating tissues of the parent tuber (Conran 2008).

There are different interpretations of the taxonomy of $D$. whittakeri, ranging from a single, very variable species (e.g. Marchant et al. 1982, Marchant 1986, Schlauer 2006); two subspecies recognised within D. whittakeri (Lowrie \& Carlquist 1992, Schlauer 1996, Clayton 2003); and/or the recognition of D. praefolia Tepper as separate from D. whittakeri (Bates 1991, Gibson 1995, Lowrie 1998, Clayton 2003, CHAH 2006).

Paper from the Australian Systematic Botany Society Conference held in Darwin, September 2007 
Drosera praefolia was distinguished from $D$. whittakeri s. lat. by its white tuber, flowers borne on lateral inflorescences that emerge before the leaves; and variably obovate, elliptic and orbicular leaves all within the same rosette (Bates 1991). Similarly, D. whittakeri subsp. aberrans Lowrie \& Carlquist was separated from subsp. whittakeri based on its few-flowered, stoloniferous, colony-forming habit.

In September 2002, Erwin Schmutz discovered an apparently new taxon on Kangaroo Island (here described as D. schmutzii), recognising that it differed from material currently included in D. whittakeri. This taxon was also collected independently by Clayton (2003), who provided informal descriptions, photographs and information about its distribution and habitat. Field observations and comparison of the plant with $D$. whittakeri and $D$. praefolia suggested that not only was this new taxon distinct, but that the other taxa associated with $D$. whittakeri were all sufficiently different to justify specific rank (Table 1).

Although three members of the complex occur on Kangaroo Island (Fig. 1), the new taxon is the only endemic. It co-occurs occasionally with $D$. praefolia and only extremely rarely with D. whittakeri s. str. (Clayton 2003), but differs from both in numerous features (Table 1), and cannot be confused easily with other members of the complex.

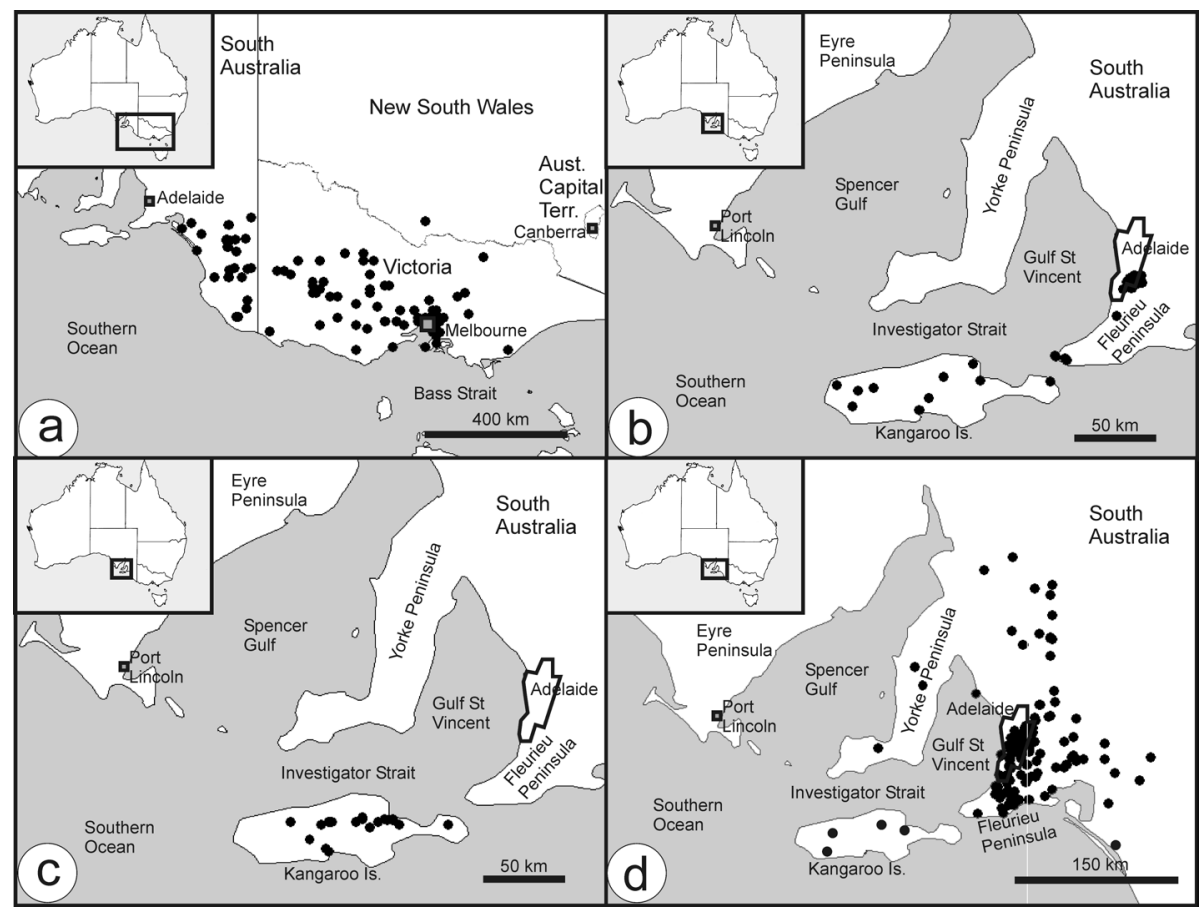

Fig. 1. Distribution maps of the Drosera whittakeri complex. a, D. aberrans; b, D. praefolia; c, D. schmutzii; d, D. whittakeri. 
Table 1. Comparison of features for taxa within Drosera whittakeri s. lat.

\begin{tabular}{|c|c|c|c|c|}
\hline Feature & D. aberrans & D. praefolia & D. schmutzii & D. whittakeri \\
\hline Mature tuber colour & pale orange & white & pale orange & orange \\
\hline $\begin{array}{l}\text { Root length } \\
\text { (comparative) }\end{array}$ & long & short & short & short \\
\hline Root hairs & dense & few & few & few \\
\hline $\begin{array}{l}\text { Laterally propagating } \\
\text { stolons }\end{array}$ & present & absent & absent & absent \\
\hline Leaf emergence & before flowering & after flowering & before flowering & before flowering \\
\hline Cauline leaves & absent & absent & whorled & absent \\
\hline Leaf disposition & $\begin{array}{l}\text { adpressed to } \\
\text { substrate }\end{array}$ & $\begin{array}{l}\text { adpressed to } \\
\text { substrate }\end{array}$ & semi-erect & $\begin{array}{l}\text { adpressed } \\
\text { to substrate }\end{array}$ \\
\hline Leaf shape & $\begin{array}{l}\text { broadly } \\
\text { spathulate }\end{array}$ & $\begin{array}{l}\text { ovate to } \\
\text { obovate }\end{array}$ & $\begin{array}{l}\text { narrowly } \\
\text { spathulate }\end{array}$ & $\begin{array}{l}\text { broadly } \\
\text { spathulate }\end{array}$ \\
\hline $\begin{array}{l}\text { Petiole shape in } \\
\text { transverse section }\end{array}$ & $\begin{array}{l}\text { weakly 3-5- } \\
\text { ridged }\end{array}$ & $\begin{array}{l}\text { lenticular, } \\
\text { slightly lunate }\end{array}$ & canaliculate & strongly 5-ridged \\
\hline $\begin{array}{l}\text { Petiole length; base } \\
\text { width; apex width } \\
(\mathrm{mm}) \text {; range and } \\
\text { mean }\end{array}$ & $\begin{array}{l}8-15(12) ; 1-1.3 \\
(1.2) ; 1.5-1.7 \\
(1.6)\end{array}$ & $\begin{array}{l}4-8(6) ; \\
1.8-2.1(2) \\
2-2.3(2.2)\end{array}$ & $\begin{array}{l}8-12(10) ; 1-1.3 \\
(1.2) ; 2-2.5(2.3)\end{array}$ & $\begin{array}{l}15-35(23) \\
4.5-5.5(5.1) \\
6-7.5(6.9)\end{array}$ \\
\hline Petiole stalked glands & absent & present & absent & absent \\
\hline Scape & absent & $\begin{array}{l}\text { ubiquitous, } 1 \text {, } \\
\text { subterranean }\end{array}$ & $\begin{array}{l}\text { common, 1-3, } \\
\text { pronounced }\end{array}$ & rare, 1, short \\
\hline Inflorescence position & terminal & lateral & terminal & terminal \\
\hline Flowers & $\begin{array}{l}\text { 1-4(-7); opening } \\
\text { successively }\end{array}$ & $\begin{array}{l}\text { up to } 10 ; \\
\text { multiple open } \\
\text { together }\end{array}$ & $\begin{array}{l}1-7 ; \text { multiple } \\
\text { open together }\end{array}$ & $\begin{array}{l}\text { up to } 20 \text {; } \\
\text { multiple open } \\
\text { together }\end{array}$ \\
\hline $\begin{array}{l}\text { Sepal length } \times \text { width } \\
(\mathrm{mm}) \text {; range \& mean }\end{array}$ & $\begin{array}{l}4-5(4.5) \times \\
2-4(2.7)\end{array}$ & $\begin{array}{l}4-5(4.6) \times \\
1.1-1.5(1.3)\end{array}$ & $\begin{array}{l}4-7.5(5.4) \times \\
1.3-3(1.9)\end{array}$ & $\begin{array}{l}6-8(6.9) \times \\
3-4(3.6)\end{array}$ \\
\hline Sepal apex shape & entire & irregularly serrate & irregularly serrate & entire \\
\hline $\begin{array}{l}\text { Petal length } \times \text { width } \\
(\mathrm{mm}) \text {; range } \& \text { mean }\end{array}$ & $\begin{array}{l}8-12(11) \times \\
5-8(6.5)\end{array}$ & $\begin{array}{l}6-9(7.5) \times \\
4-5(4.4)\end{array}$ & $\begin{array}{l}10-14(12.3) \times \\
7-9(8)\end{array}$ & $\begin{array}{l}10-12(11.2) \times \\
6-10(8.8)\end{array}$ \\
\hline Petal apex shape & retuse & $\begin{array}{l}\text { crenulate } \\
\text {-retuse }\end{array}$ & retuse & $\begin{array}{l}\text { truncate } \\
\text {-crenulate }\end{array}$ \\
\hline Anthers & yellow & yellow & white & white \\
\hline Pollen & yellow & $\begin{array}{l}\text { glassy, pale } \\
\text { yellow }\end{array}$ & yellow & pale yellow \\
\hline Stigma lobing & unlobed (single) & 2-lobed & unlobed (single) & 4-lobed \\
\hline Stigma apex & rounded & rounded & rounded & flat \\
\hline Pedicels in fruit & decumbent & $\begin{array}{l}\text { decumbent, } \\
\text { under foliage }\end{array}$ & arching & $\begin{array}{l}\text { decumbent, rarely } \\
\text { arching }\end{array}$ \\
\hline Seed shape (fig. 3) & ovoid-cylindrical & ovoid & irregularly cuboid & $\begin{array}{l}\text { angular ovoid- } \\
\text { cylindrical }\end{array}$ \\
\hline $\begin{array}{l}\text { Seed length } \times \text { width } \\
(\mathrm{mm}) \text {; range \& mean }\end{array}$ & $\begin{array}{l}1-1.3(1.2) \times \\
1-1.3(1.1)\end{array}$ & $\begin{array}{l}0.7-1(0.8) \times \\
0.4-0.8(0.7)\end{array}$ & $\begin{array}{l}1.3-1.5(1.4) \times \\
0.8-1.5(1.1)\end{array}$ & $\begin{array}{l}1-1.3(1.2) \times \\
0.7-1(0.9)\end{array}$ \\
\hline $\begin{array}{l}\text { Seed cell sculpturing } \\
\text { (Fig. 3), terminology } \\
\text { follows Barthlott }\end{array}$ & $\begin{array}{l}\text { irregularly } \\
\text { hexagonal } \\
\text { with thickened } \\
\text { anticlinal } \\
\text { margins }\end{array}$ & $\begin{array}{l}\text { irregularly } \\
\text { hexagonal } \\
\text { with thickened } \\
\text { anticlinal } \\
\text { margins }\end{array}$ & $\begin{array}{l}\text { strongly irregular } \\
\text { hexagonal } \\
\text { with weakly } \\
\text { thickened anticlinal } \\
\text { margins }\end{array}$ & $\begin{array}{l}\text { irregularly } \\
\text { hexagonal } \\
\text { with weakly } \\
\text { thickened } \\
\text { anticlinal } \\
\text { margins }\end{array}$ \\
\hline
\end{tabular}


There have been some studies of $D$. whittakeri s. lat., mainly on nutrient-related physiology (Chandler \& Andersson 1976) and pigment chemistry (Cooke \& Segal 1950), but no overall examination of morphological variation throughout its distributional range. Chandler and Andersson (1976) found that vegetative propagation in Victorian $D$. aberrans (referred to as ' $D$. whittakeri') was regulated by the availability of nutrients; with plants that showed above-average phosphorous levels being more likely to produce multiple, secondary tubers. This reflects the fact that these taxa, unlike many of their tuberous Western Australian counterparts, often grow on soils that are not as severely nutrient-limited (Pate \& Dixon 1982). Jeffrey (1967) further found that plants in poor soils on the Ninety-Mile Plain near Keith, South Australia (here recognised as $D$. aberrans) grew embedded in and associated with the phosphate-collecting surface proteoid root mats of Banksia ornata F.Muell. ex Meisn. (Proteaceae). This is further supported by Clayton's (2003) observations that D. whittakeri s. lat. responds well to regular applications of half-strength fertilizer, unlike the majority of native Droseraceae.

\section{Methods}

Living specimens both in the field and in cultivation were examined for the characteristics listed in Table 1, as were the accessions held at AD, ADU, MEL and PERTH. This resulted in the measurement and comparison of 162 D. whittakeri, 105 D. aberrans, 38 D. praefolia and 35 D. schmutzii collections. As tuber colour intensity can vary with maturity, only fully-developed tubers from mature plants at dormancy were used for comparison.

Predictive distribution modelling used the Predicted Distribution module in Biolink 2.0.5 (Shattuck 2003) with default climatic parameters and the Gower Metric (DOMAIN) option; all known localities for D. schmutzii; and parameter tolerances set to $75 \%$ and $50 \%$ with contour mapping intervals of $10 \%$ and a lower cut-off of $30 \%$.

\section{Taxonomy}

Features such as flower number (which might be expected to be influenced by environment) and seed size and shape (which can be affected by development) differ consistently across the range of materials examined, further supporting their segregation as separate species (Table 1). Four species are here recognised within Drosera whittakeri s. lat.

\section{Key to species in Drosera whittakeri s. lat.}

1 Leaves emerging before flowering; inflorescence terminal

$1^{\star}$ Leaves emerging after flowering; inflorescence lateral

D. praefolia

2 Plants stoloniferous; flowers few, opening in succession

D. aberrans

$2^{\star}$ Plants not stoloniferous; flowers numerous, several opening together 3

3 Leaves narrowly canaliculate-petiolate, cauline leaves whorled D. schmutzii

$3^{*}$ Leaves obovate, flat, tapering basally, cauline leaves absent D. whittakeri 


\section{Drosera aberrans (Lowrie \& Carlquist) Lowrie \& Conran, comb. \& stat. nov.}

D. whittakeri subsp. aberrans Lowrie \& Carlquist, Phytologia 73(2): 98, 113 \& 115 Fig. 8 (1992); F.Muell. The Native Plants of Victoria Succinctly Defined, p. 53 (1879) (as 'D. whitackeri')

Type: South Australia: in red loam soils in mallee scrub country west and east of Sherlock, 19 July 1991, D.E. Murfet 1059 (holo: PERTH; iso: RSA).

Illustrations: Mueller (1879) Fig. 10; Lowrie \& Carlquist (1992) Fig. 8; Lowrie (1998: 257); Lowrie (1998: 259 photos).

Perennial herb, colony-forming, tuberous, stoloniferous, green, orange-yellow or red, with leafy rosette, $3-5 \mathrm{~cm}$ diam. Tuber pale orange, \pm broadly obovoid, c. $8 \mathrm{~mm}$ long, c. $8 \mathrm{~mm}$ diam., enclosed in a number of black papery sheaths at the end of a vertical subterranean stem $4-5 \mathrm{~cm}$ long. Leaves broadly spathulate, adpressed to soil surface, often turning redder with age, with 8-12 leaves per rosette; petiole 8-15 mm long, 1-1.3 mm wide at base, dilated to 1.5-1.7 $\mathrm{mm}$ wide distally (at base of lamina), longitudinally weakly 3-5 ridged, margin entire, glabrous; lamina obovate to broadly obovate, 5-11 mm long, 6-11 mm wide, length and width commonly variable within same rosette, margin basally entire, distally dentate, with apex dentate (more readily observed on abaxial surface), with glandular trichomes terminating each apical dentate marginal segment, insect-catching glands positioned on adaxial surface near margin of lamina, with slightly shorter glands medially, trichomes green to translucent red with dark red glandular heads, abaxial lamina glabrous, veins branched towards apex (more readily observed in dried specimens). Inflorescence consisting of 1-4 (rarely to 7) flowers arising from centre of rosette and opening singly in succession, pedicels \pm similar in colour to leaves, 1-4 cm long, sparsely covered with scattered sessile glands, pedicels decumbent in fruit. Sepals green to reddish, lanceolate, 4-5 mm long, 2-4 mm wide, margin entire, apex entire, abaxial surface black dotted (more easily observed in dried specimens), with small number of scattered minute sessile glands similar to those found on scape, otherwise glabrous. Petals white, cuneate, margin entire, apex retuse, 8-12 mm long, 5-8 $\mathrm{mm}$ wide. Stamens 5, 4-4.5 $\mathrm{mm}$ long, filaments white, anthers yellow, pollen yellow. Ovary green, obovoid, 1.7-2 mm long, 1.6-1.9 mm diam. Styles and stigmas 3, white, 1.6-1.8 $\mathrm{mm}$ long, each divided into many filiform branching segments, glabrous, stigmatic portion white, slightly dilated apically into a single, rounded, knob-like projection, papillose. Seed charcoal black, ovoid-cylindrical, 1-1.3 mm long, 1-1.3 mm diam., surface sculpture irregularly hexagonal with thickened anticlinal margins; micropyle within indented basal pole, apical pole rounded. (Figs $2 \mathrm{a}, \mathrm{b} \& 3 \mathrm{a}, \mathrm{b}$ )

Habitat: common in a wide range of soil types from sands to lateritic gravels and limestone-derived clays. The plants grow in full sun or partial shade in mallee woodlands, heaths and open forested regions.

Distribution: widespread across the inland southern mallee regions of South Australia east of the Mount Lofty Ranges, southern and central Victoria to east of Wilson's Promontory. A single collection is reported from southern central New South Wales (Fig. 1a).

Conservation status: common and well represented in conservation areas. Not threatened. 

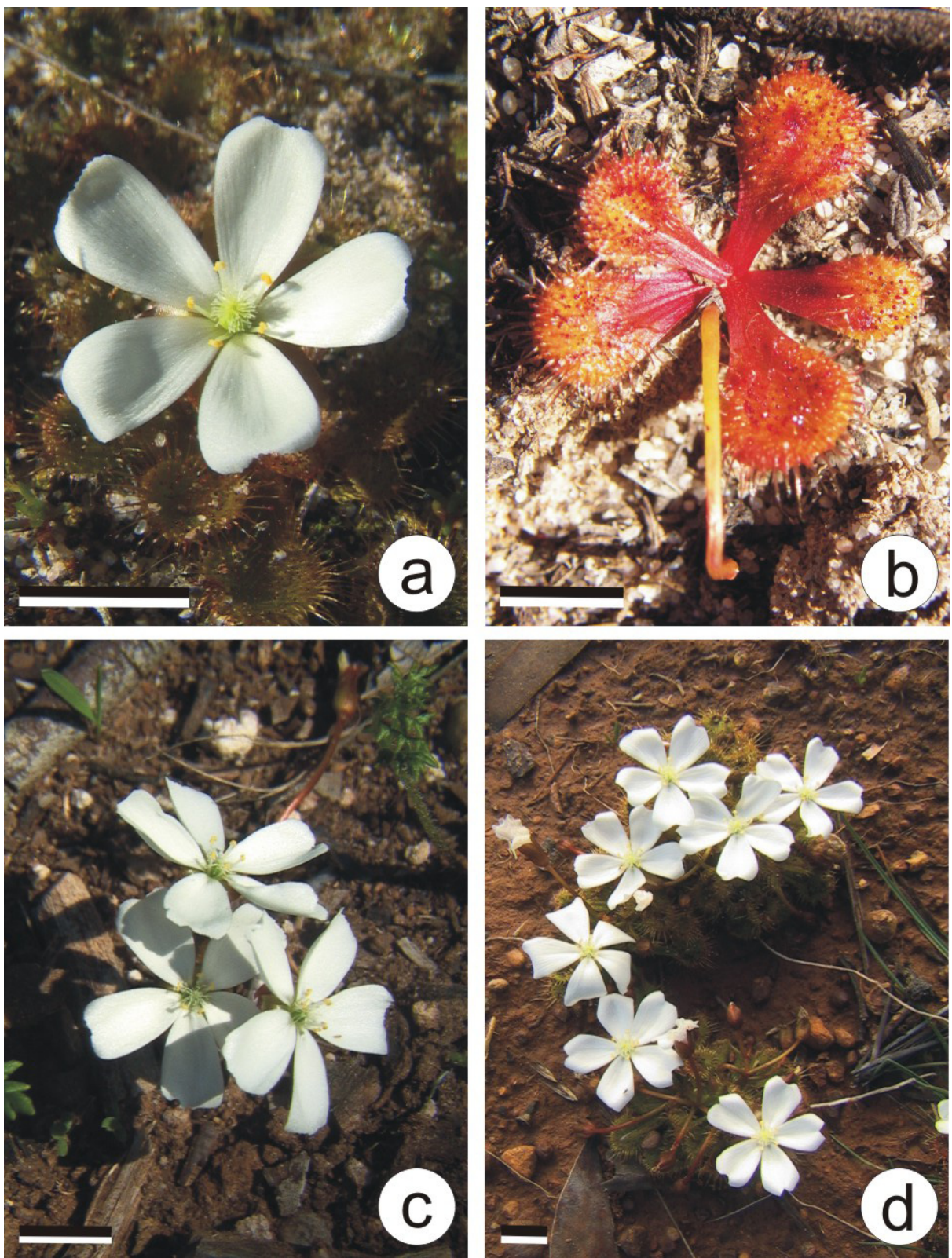

Fig. 2. Members of Drosera whittakeri Planch. complex other than D schmutzii, showing distinctive characteristics. a, D. aberrans (Lowrie \& S. Carlquist) Lowrie \& Conran, habit with typically 1-flowered plant (Conran 2014); b, same showing lateral stolons (Conran 1563); c, D. praefolia Tepper with precocious lateral inflorescence emerging before the leaves (Conran 1972); d, D. whittakeri with robust, simultaneously multi-flowered habit (Conran 1971). Scale bars $10 \mathrm{~mm}$. 

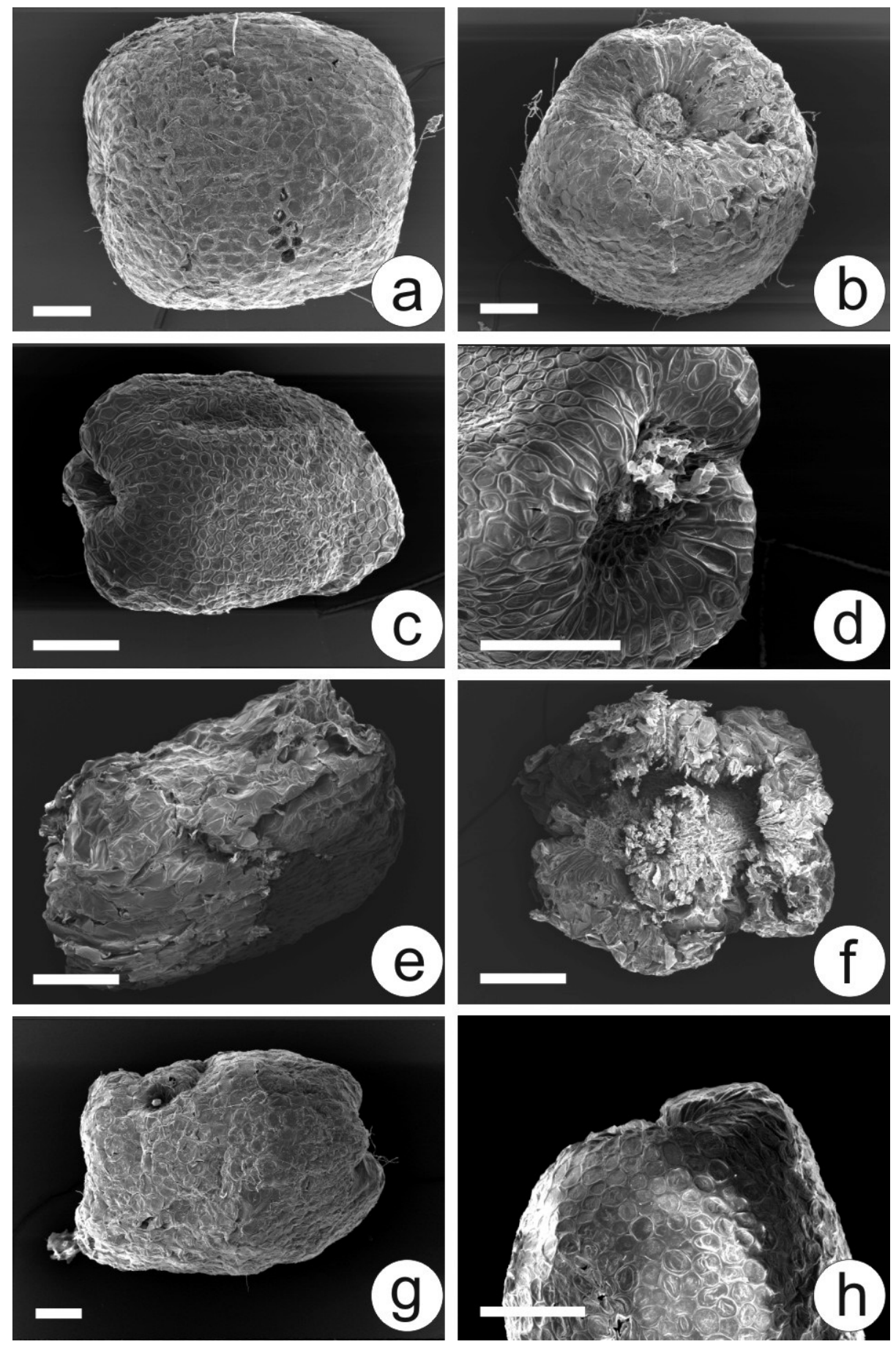

Fig. 3. Seeds of the Drosera whittakeri complex. a, D. aberrans (Lowrie 2836) lateral view; b, micropylar view; c, D. praefolia (Conran 1972) lateral view; d, micropylar view; e, D. schmutzii (Conran 1525) lateral view; f, micropylar view; g, D. whittakeri (Lowrie 2831) lateral view; h, micropylar view. Scale bars $200 \mu \mathrm{m}$. 
Notes: Drosera aberrans flowers July-September and has a dry dormancy period as a subterranean tuber over summer. The species regularly multiplies asexually, producing axillary stolons that occur along the vertical subterranean stem and frequently from the centre of the parent rosette. These stolons develop above the soil surface until clear of the parent plant, and then burrow into the soil where additional tubers are produced. As a result of this stoloniferous propagation, large, mat-like, compact colonies of rosettes are produced. Possibly because of this, not many flowers are produced in most years, a single colony of several hundred ramets often only making a few flowers per season, and generally only 1-4 per flowering shoot, although plants on more fertile soils may produce more flowers (rarely up to seven per plant) and more regularly. Unlike the other species described here, the flowers appear to open singly in succession on each shoot. The scent is (subjectively) sweet and similar to D. schmutzii, but differing from $D$. praefolia and D. whittakeri. Leaf colour does not appear to be a function of exposure, as green, orange and red-leaved forms grow together at many sites as adjacent unicoloured colonies, both in shade and full sun, and maintain these colours under uniform cultivation conditions (pers. obs.), although leaves also tend to become more red with age.

Mueller (1879) illustrated this taxon (as D. whitackeri [sic]) with two rosettes arising from a single, branched vertical shoot arising from the tuber, but there are no specimens at MEL or anywhere else that appear to show this and this may represent artistic licence.

Although the ranges of D. aberrans and D. whittakeri do overlap briefly at the Coorong National Park and Monarto Conservation Park, SE of Adelaide, there is no evidence of intermediate specimens.

Selected specimens examined: New South Wales: Edward River. Riverina (353 $\left.31^{\prime} \mathrm{S} 144^{\circ} 55^{\prime} \mathrm{E}\right)$, Sullivan s.n., 1876 (MEL96947A). South Australia: Coorong National Park (36 11'32"S, 13940'39"E), Robinson 1480 \& Casperson, 8 Jul 1987 (AD98807443); Bangham Conservation Park (36³6'0"S, 14054'0"E), Murfet 1605, 3 Oct 1992 (AD99249185); Malinong Scrub (35³3'58"S, 139³2'35"E), Murfet 3875, Taplin \& Eckert, 3 Aug 2001 (AD123197); EP 150 Nangwarry (37³2'37"S, 14048'56"E), Wilson, 829, 1 Jul 1968 (AD96936147); North Horseshoe Native Forest Reserve (37²0'S, 14050'E), Meznar 2, 15 Aug 1984 (AD98520133); Wirrega Railway Station (36²'25"S, 140³4'54"E), Osborn s. n., 2 Oct 1915 (AD97618594); Mount Watch, The Bluff (37²3'40"S, 140³4'12"E), Lothian 2912, 26 Aug 1964 (AD96511062); Wright Swamp Road (38 $4^{\circ}$ 'S, $\left.141^{\circ} 20^{\prime} \mathrm{E}\right)$, Dodson 14211, 19 Sep 1972 (AD97241164); Monarto Con-

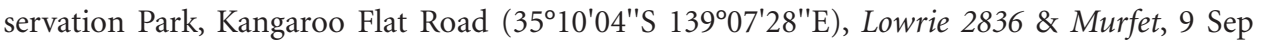
2003 (AD, PERTH, MEL); University of Adelaide research campsite, Mount Rescue Conservation Park (3556'56.8"S 140²1'36.8"E), Conran 1563, 18 Sep 2004 (AD, ADU). Victoria: Ring-

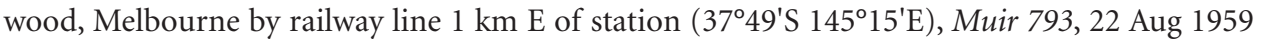
(MEL96919A); You Yangs (37²5'S 1442ㄴ'E), Walter s.n., Aug 1900 (MEL96928A); Wangaratta (36²1'S 146 $\left.19^{\circ} \mathrm{E}\right)$, Collector unknown, 24 Jul 1907 (MEL96934A); Anglesea, Le Breton s.n.,

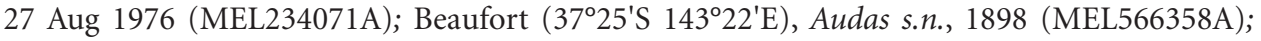

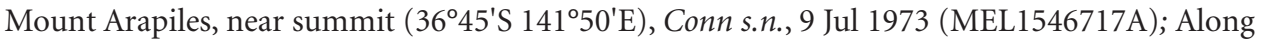

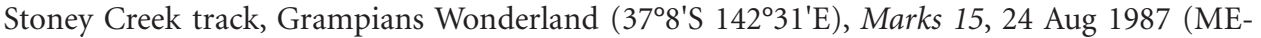

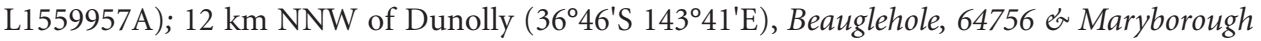
Field Naturalist's Club, 9 Sept 1979 (MEL1577737A); Brisbane Ranges National Park, McLeans Highway, E of Switchback Road Junction, $6.5 \mathrm{~km} \mathrm{~N}$ of Anakie (37 $52^{\prime} \mathrm{S} 144^{\circ} 15^{\prime} \mathrm{E}$ ), Beauglehole 56600, A. \& Errey, 1 Oct 1977 (MEL1577744A); Point Nepean National Park, Greens Bush, bounded by Rogers and Greens Roads. Grid Ref.: CT193430 - CT194448 (38²6'S 14455'E), Connock 113, 17 Aug 1990 (MEL1592726A). 
Drosera praefolia Tepper, Bot. Centr. 50: 357 (1892)

D. bulbosa Hook. var. praefolia (Tepper) R.Hamet, Bull. Soc. Bot. France 54: 70 (1907)

D. whittakeri var. praefolia (Tepper) J.M.Black, Fl. S. Aust. Pt 2, 258 (1924)

D. whittakeri subsp. praefolia (Tepper) Lowrie, Bull. Austral. Carniv. Pl. Soc. 8: 47 (1989)

D. aphylla Tepper ex R.Bates, J. Adelaide Bot. Gard. 14: 99 (1991) nom. illeg.

Type: "Im August 1881 langte ich in Clarendon an, um das Dorf für einige Zeit zu meinem Wohnsitze zu machen. Vorher war ich für einige Jahre im nordöstlichen Theile von Yorke's peninsula [Clarendon, Mount Lofty, South Australia, Tepper 618]" (holo: MEL).

Illustrations: Lowrie (1998: 217); Lowrie (1998: 219 photos).

Perennial herb, solitary, tuberous, green, or sometimes red (in full sunshine), with a leafy rosette, 4-6 cm diam.. Tuber white, \pm globose, 6-8 $\mathrm{mm}$ long, 6-8 $\mathrm{mm}$ diam., enclosed in a number of black papery sheaths at the end of a vertical subterranean stem 3-5 cm long. Leaves obovate, absent at anthesis, adpressed to soil surface, with 8-16 leaves per rosette; petiole 4-8 $\mathrm{mm}$ long, c. $2 \mathrm{~mm}$ wide at base, slightly dilated distally at base of lamina, lenticular and slightly lunate in section on the upper leaves, less so on the lower leaves, margins slightly revolute, glandular; vernation involute; lamina ovate to obovate, $10-16 \mathrm{~mm}$ long, $8-12 \mathrm{~mm}$ wide, length and width commonly variable within the same rosette, margin entire, distally dentate with apex dentate (more readily observed on abaxial surface), with glandular trichomes terminating each apical dentate marginal segment, insect-catching glands positioned on adaxial surface near margin of lamina, with slightly shorter glands medially, trichomes green to translucent red with dark red glandular heads, abaxial lamina glabrous, veins branched towards apex (more readily seen in dried specimens). Inflorescence a lateral, subterranean scape emerging prior to the leaves. Flowers up to 10, terminal on scape, pedicels green to red, 2.5-5 cm long, sparsely covered with scattered sessile glands, pedicels decumbent and \pm underneath leaf rosette in fruit. Sepals reddish, narrowly ovate to lanceolate, 4-5 $\mathrm{mm}$ long, 1.1-1.5 mm wide, margins entire, apex irregularly serrate, abaxial surface black dotted (more easily seen in dried specimens), glabrous. Petals white, cuneate, margins entire, apex crenulate-retuse, 6-8 mm long, 3-4 mm wide. Stamens 5, 3-3.5 mm long, filaments white, anthers yellow, pollen glassy, pale-yellow. Ovary green, obovoid, 1-1.2 mm long, 1-1.2 mm diam. Styles and stigmas 3, white, 1.2-1.4 mm long, each divided into many filiform branching segments, glabrous, stigmatic portion white, apically 2-lobed, slightly dilated, papillose. Seed charcoal black, ovoid, 0.7-1 mm long, 0.4-0.8 mm diam., micropyle within indented basal pole, apical pole rounded, surface sculpture irregularly hexagonal with thickened anticlinal margins. (Figs $2 \mathrm{c} \& 3 \mathrm{c}, \mathrm{d}$ )

Habitat: the species generally grows in exposed, dry sites or open woodland on loams, decomposed shales or lateritic clay-sand. It flowers in moderate shade as well as full sun and does not need fire to trigger flowering.

Distribution: Drosera praefolia occurs in south-east South Australia along the southern Fleurieu Peninsula south of Adelaide, extending to Kangaroo Island. (Fig. 1b)

Conservation status: well represented in conservation areas and not considered to be threatened, despite its relatively narrow distribution. 
Notes: the species flowers April-May, often shedding its seeds before leaf production, and has a dry dormancy period as a subterranean tuber over summer. Leaf colour varies from green to red in this species, but unlike D. aberrans and D. whittakeri, redder leaves seem to be more a response to exposure to sunlight.

Although described by Tepper (1892) from material he collected on the Fleurieu Peninsula near Adelaide, the species was largely ignored, or regarded as a poorly known, precocious-flowering variant of D. whittakeri (Marchant et al. 1982, Marchant 1986), despite the very detailed account of its form and phenology sent by Tepper to Mueller in 1882 along with specimens (correspondence held at MEL). Mueller annotated the sheets as D. whittakeri var. aphylla, but the name was never published, nor did Mueller adopt Tepper's name. Bates (1991) demonstrated clearly that D. praefolia is distinct from $D$. whittakeri s. lat. by: its white tuber; habit of flowering on a lateral inflorescence before leaves emerge; and the possession of obovate, elliptic and/or orbicular leaves within the same rosette, 2-lobed stigmas and the highly unusual (for the family) involute leaf vernation. Nevertheless, despite being recognised at subspecific (Lowrie 1989) and later, specific rank (Gibson 1995, Lowrie 1998, CHAH 2006), D. praefolia continues to be regarded as part of D. whittakeri by some authors (e.g. Barker et al. 2005, Schlauer 2006). However, its numerous differences from the other species described here strongly support its recognition at species rank.

Selected specimens examined: South Australia: Talisker Conservation Park along walking trail

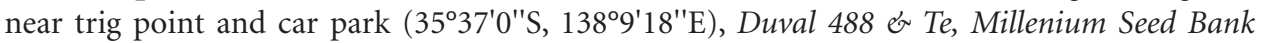
Partnership, 19 Jun 2006 (AD198072); SA Water, Mount Bold Reservoir land off Scenic Road, Clarendon (356'57"S, 13840'0"E), Robertson 225, 22 Apr 1999 (AD99917188); From scrubland

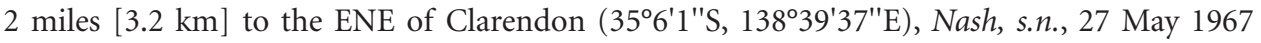
(AD96725303); Approximately 2.3 miles [3.7 km] due W of Clarendon (356'41"S, 138 $34^{\prime} 23^{\prime \prime E}$ ), Nash, s.n., 9 Apr 1967 (AD96717033); In scrubland at Cherry Gardens, c. 22 km SSE of Adelaide (353'55"S, 138³9'55"E), Smith, 1856, 28 Apr 1972 (AD97413171); Onkaparinga National Park (358'33"S, 138³5'16"E), Murfet 3163, 9 Apr 1998 (AD99906226); Deep Creek Conservation

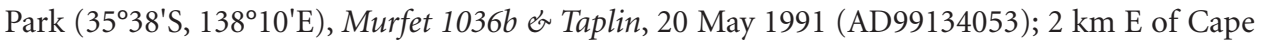
Jervis (3536'S, $138^{\circ} 5^{\prime} \mathrm{E}$ ), Bates 16892, 10 Apr 1989 (AD99032067); Top of Willunga Hill (3520'S, $138^{\circ} 30^{\prime} \mathrm{E}$ ), Bates 17555, 10 May 1989 (AD99032066); $6.65 \mathrm{~km}$ NW of Cape St. Albans Lighthouse (3546'53"S, 138 3'24"E), Overton, Canty \& Kinnear, S. A. NPWS Kangaroo Island Survey, NPKI40873, 19 Nov 1989 (AD99026189); 8.5 km NE of Parndana (35²4'55"S, 137²0'17"E), Croft \& Dennis, S. A. NPWS Kangaroo Island Survey, NPKI40038, 13 Nov 1989 (AD99026187); On track into Gosse Crown Lands from Playford Highway about 2.5 miles [4 km] S of highway (3549'10"S, 13652'0"E), Jackson 1516, 12 Apr 1982 (AD98231202); $9.5 \mathrm{~km}$ from Cape

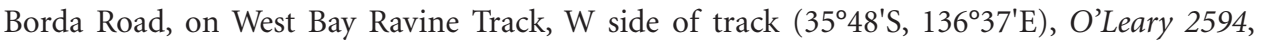

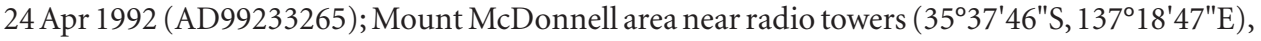
Murfet 5349, 20 Aug 2006 (AD199083); Rex Ellis'property, Hundred of Borda (3550'19http:// www.vinodiversity.com/viticulture-and-environment.htmlS, $136^{\circ} 45^{\prime} 38^{\prime \prime E}$ ), Jackson 1522, 26 Apr 1982 (AD98231196); Wittow Creek, $1.75 \mathrm{~km} \mathrm{~S}$ of East West Highway II, $0.5 \mathrm{~km} \mathrm{~W}$ of

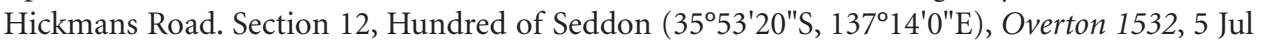
1991 (AD99143016); 7 km W of Rocky River Park H. Q. Rocky River floodplain (3556'54"S, 136³'39"E), Robinson \& Halstead, S. A. NPWS Kangaroo Island Survey, NPKI10547, 7 Nov 1989 (AD99026183); From paddock behind Old Cemetery, Kingscote (35³9'21"S, 137³8'8"E), Jackson 615, 10 May 1969 (AD96949048); Vivonne Bay, S coast. 750 m E of Harriet River bridge,

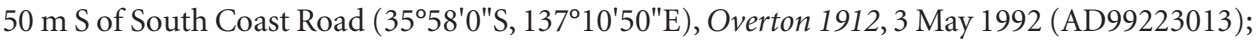
Beyeria Conservation Park, W boundary, Willsons Road, $3 \mathrm{~km}$ E of Hundred Line Road $\left(35^{\circ} 46^{\prime} \mathrm{S}\right.$, 137³5'E), Overton 1941, 22 May 1992 (AD99232117); Piggot Range Road, Southern Mount Lofty Ranges (358'9.2"S 138³5'13.1"E), Conran 1972, 5 Jul 2006 (AD, ADU). 


\section{Drosera schmutzii Lowrie \& Conran, sp. nov.}

Affinis Drosera whittakeri sed saepe breviter caulina. Folia rosularia spathulata petiolata et folia caulina verticillata (D. stolonifera similis); petioli angusti canaliculati. Petala obovata, truncata, alba, 10-14 mm longa, 7-9 mm lata. Semina nigra, oblongairregularis, ruminata-reticulata, ad apicem et basi indenta, 1.3-1.5 mm longa, 1.2$1.5 \mathrm{~mm} \times 0.8-0.9 \mathrm{~mm}$ lata .

Type. South Australia: corner of South Coast Road and Elsegood Road, c. $20 \mathrm{~km}$ south of Kingscote, Kangaroo Island (3546'11"S, 137³3'34"E), 6 Sep 2003, A. Lowrie 2816 \& D.E. Murfet (holo: AD; iso: PERTH, MEL).

Perennial herb, solitary, tuberous, green to red, with a leafy rosette, $3-4 \mathrm{~cm}$ diam. at anthesis. Tuber pale orange, \pm broadly obovoid, c. $8 \mathrm{~mm}$ long, c. $8 \mathrm{~mm}$ diam., depressed laterally, enclosed in a number of dark brown papery sheaths at the end of a vertical subterranean stem 4-5 cm long. Leaves narrowly spathulate, few leaves adpressed to the soil surface, most semi-erect, a second distal leaf whorl often present on a stem c. $10 \mathrm{~mm}$ long (resembling the leaves of D. stolonifera), with 8-10 leaves per rosette; petioles 8-12 $\mathrm{mm}$ long, $1-1.3 \mathrm{~mm}$ wide at base, dilated to $2-2.5 \mathrm{~mm}$ wide distally at base of lamina, adaxially canaliculate in section on distal leaves, less so on basal leaves, longitudinally ridged, margins entire, glabrous; lamina obovate to broadly obovate, 5-9 mm long, 6-11 mm wide at anthesis, length and width of lamina commonly variable within same rosette, longitudinally depressed adaxially for two thirds, distal lamina often incurvedlunate (resembling D. stolonifera leaves), basal margins entire, distal margins dentate with apex dentate (more readily observed on abaxial surface), with glandular trichomes terminating each apical dentate marginal segment, insect-catching glands positioned on the adaxial surface near margin of lamina with slightly shorter glands medially, trichomes translucent red with dark red glandular heads, abaxial lamina glabrous, veins branched towards the apex (more readily observed in dried, blackened specimens). Inflorescence consisting of 1-3 terminal, short to elongated scapes, or flowers \pm arising from the centre of the rosette. Flowers usually 2-7, pedicels \pm similar in colour to leaves, $2.5-4 \mathrm{~cm}$ long, sparsely covered with scattered sessile glands, pedicels arching downwards in fruit. Sepals reddish, narrowly ovate to lanceolate, 4-7.5 mm long, 1.3-3 mm wide, margins entire, apex a little irregularly serrate, abaxial surface black dotted (more easily observed in dried specimens), with a small number of scattered minute sessile glands similar to those found on the scape, otherwise glabrous. Petals adaxial and abaxial surface white, obovate, margin entire, apex retuse, 10-14 $\mathrm{mm}$ long, 7-9 mm wide. Stamens 5, 3-3.5 mm long, filaments white, anthers white, pollen yellow. Ovary green, obovoid, 1.2-1.5 mm long, 1.2-1.3 mm diam. Styles and stigmas 3, white, 1-1.5 mm long, each divided into many filiform branching segments, glabrous, stigmatic portion white, slightly dilated apically into single knob-like projection, papillose. Seed charcoal black, irregularly cuboid, sides \pm flattened, $1.3-1.5 \mathrm{~mm}$ long, 1.2-1.5 mm wide, $0.8-0.9 \mathrm{~mm}$ thick, micropyle small, \pm hidden within an indented basal pole, apical pole indented, surface sculpture strongly irregular hexagonal, with weakly thickened anticlinal margins. (Figs 3 e, f; 4 \& 5)

Etymology: the Latinised epithet schmutzii honours Father Erwin Schmutz SVD (Society of the Divine Word) of the German Catholic Centre, Collinswood South Australia who discovered this species. He is an accomplished and passionate field naturalist of flora, fauna and geology in Indonesia and South Australia.

Habitat: Drosera schmutzii commonly grows in buff-yellow sandy clay with laterite 


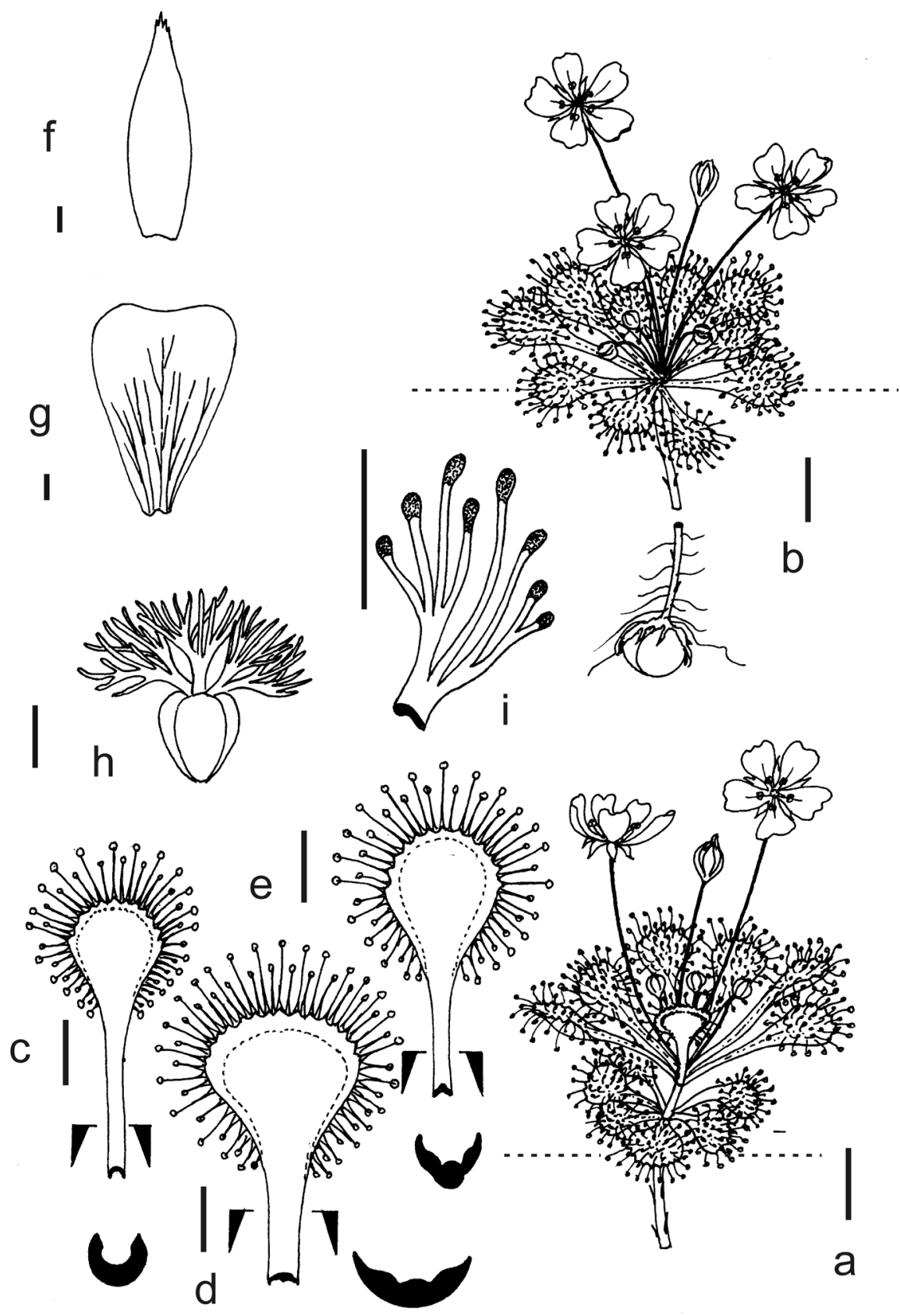

Fig. 4. Drosera schmutzii Lowrie \& Conran. a, plant showing whorled distal leaves on stem; b, plant; c, cauline lamina; d, proximal basal rosette lamina; e, distal basal rosette lamina; f, sepal; g, petal; $\mathbf{h}$, ovary and styles; i, style-stigmas, enlarged. Scale bars $10 \mathrm{~mm}$ (a, b), $5 \mathrm{~mm}$ $(\mathrm{c}-\mathrm{e})$, and $1 \mathrm{~mm}(\mathrm{f}-\mathrm{i})$. Drawn by A. Lowrie from live material collected from the type location (A. Lowrie 2816 \& D.E. Murfet) 

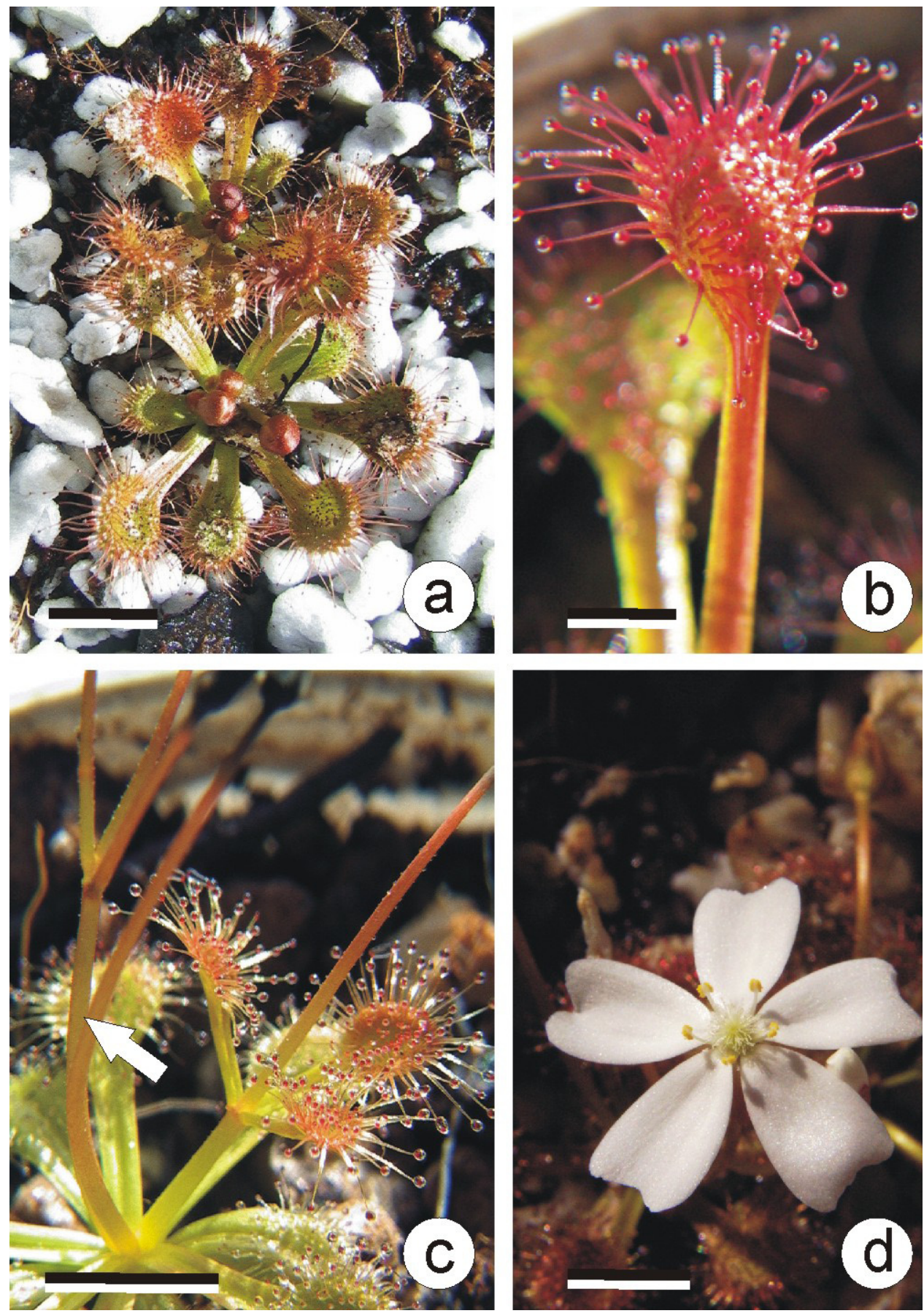

Fig. 5. Drosera schmutzii (Conran 1525). a, habit; b, leaf showing narrow, semi-erect, canaliculate petiole; c, whorled cauline leaves and flowering scape (arrow); d, flower. Scale bars $10 \mathrm{~mm}$ (a, c, d) and $2 \mathrm{~mm}(\mathrm{~b})$. 
pebbles, with the underlying rock sandstone, in open sunny areas amongst Allocasuarina muelleriana (Miq.) L.A.S.Johnson (Casuarinaceae). It has also been found on red, ironand aluminium-rich clay with iron-rich, pisolith (pea-like) gravels; Macgillvray white sands (derived from dune sands) with laterite intrusions; and in sandy soils in small shallow gnamma holes in sheet limestone cap rock overlooking the ocean. The species often grows with another Kangaroo Island endemic: Stylidium tepperianum (F.Muell.) Mildbr. (Stylidiaceae). All of these habitats are dry in summer.

Distribution: Drosera schmutzii is a Kangaroo Island endemic that occurs across the island, but seems to be mainly in the northern and eastern areas (Fig. 1c). It occurs along the $\mathrm{N}$ and $\mathrm{E}$ boundaries of the Flinders Chase National Park, but does not seem to be widespread inside the park, although this may represent lack of collecting.

Conservation status: although common across the island and not immediately threatened, the majority of collections have been from areas that are subject to human impact (e.g. along roadsides) or are not in reserves.

Notes: the species flowers from late June to September and has a dry dormancy period as a subterranean tuber over summer. Leaf colour varies from green to red in this species, but unlike D. aberrans and D. whittakeri, redder leaves seem to be a response to exposure to sunlight.

Drosera schmutzii is distinguished by its very narrow, canaliculate, eglandular petioles (Fig. 5b); semi-erect leaves (Fig. 5a, c) and frequent presence of whorled leaves on a short axis (Fig. 5c), resembling the leaves of D. stolonifera Endl. It is further distinguished by its larger, irregularly cuboid seeds with very irregular testal sculpturing (Fig. 3e-f). These characteristics, as well as the differences noted between the other members of the D. whittakeri complex were consistent across the material examined, as well as for specimens grown under cultivation for several years by both authors. Even though there is some geographic and/or habitat overlap between the different taxa, at those few places where two or more of the complex co-occur there was no evidence in intergradations between them.

It was at first thought that another larger, many-leaved, rosette-forming, multiflowered taxon, related to the Drosera whittakeri complex occurred on Kangaroo Island (in addition to D. whittakeri, D. schmutzii and D. praefolia). However, while it occurs frequently on the island, it proved to be just a very robust form of D. schmutzii when grown in cultivation, apparently analogous to the robust forms of D. whittakeri s. str. from the Adelaide Hills. Although D. schmutzii grows in a range of habitats across the island, and often co-occurs with D. praefolia, it is only very rarely found growing with D. whittakeri (Clayton 2003 and pers. obs. by both authors).

Climatic predictive distribution modelling at 75\% tolerance (Fig. 6a) shows that the species is effectively confined to Kangaroo Island, with only possible extensions to the southernmost Fleurieu and Yorke Peninsulas under the 50\% tolerance model (Fig. 6b). However, extensive searches in these areas failed to find any plants resembling D. schmutzii and in any case, D. whittakeri s. lat. is almost completely absent from the Yorke Peninsula. 

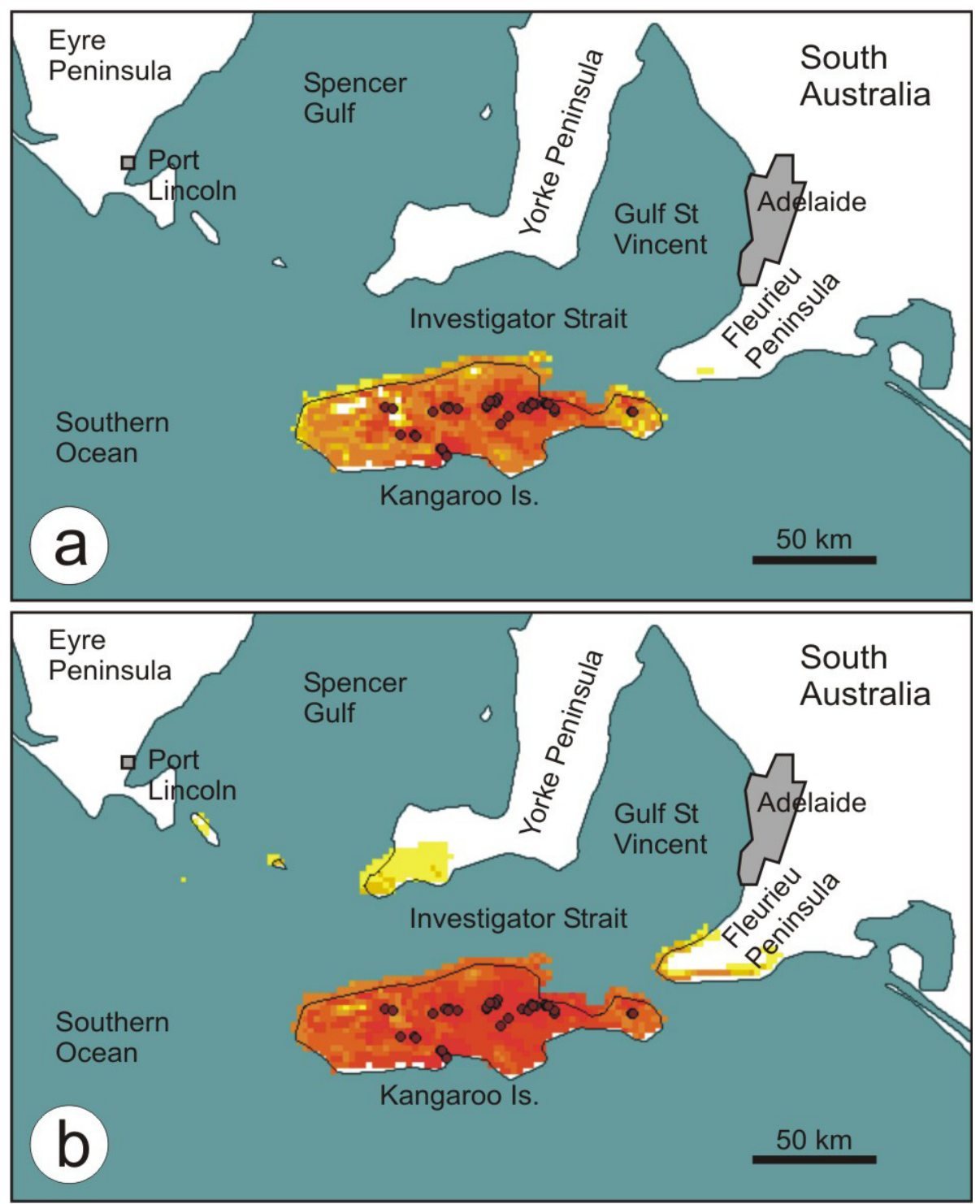

Fig. 6. Predictive distribution modelling for Drosera schmutzii using BIOLINK. a, distribution pattern under $75 \%$ tolerance; b, model under 50\% tolerance. Darker areas are those with higher predicted probability of occurrence.

Selected specimens examined: South Australia: Kangaroo Island: South Coast Road, 24 Sep 2002, Schmutz 8051 (AD, PERTH, MEL); Moffartt Road (3548'12"S 13759'19"E), Lowrie 2804 \& Murfet, 6 Sep 2003 (AD, PERTH, MEL); Hog Bay Road (3547'45"S 137³9'22"E), Lowrie 2807 \& Murfet, 6 Sep 2003 (AD, PERTH, MEL); South Coast Road, Emu Ridge (354'ㄴ'36"S 137³2'28"E), Lowrie 2815 \& Murfet, 6 Sep 2003 (AD, PERTH, MEL); Junction of South Coast Road \& Elsegood Road (3546'11"S 137³3'34"E), Lowrie 2816 \& Murfet, 6 Sep 2003 (AD, PERTH, MEL); Junction

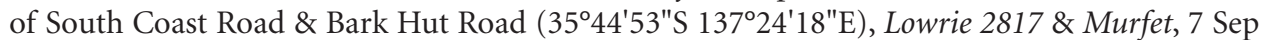

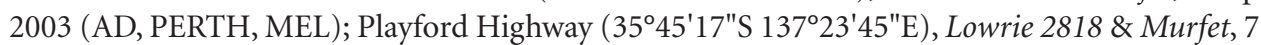


Sep 2003 (AD, PERTH, MEL); Playford Highway (3546'42"S 137²1'45"E), Lowrie 2819 \& Murfet, 7 Sep 2003 (AD, PERTH, MEL); Playford Highway, junction of McHughes Road (3547'17"S $137^{\circ} 11^{\prime} 43^{\prime \prime E}$ ), Lowrie 2820 \& Murfet, 7 Sep 2003 (AD, PERTH, MEL); Mount Stockdale Road (3554'34"S 13703'25"E), Lowrie 2823 \& Murfet, 7 Sep 2003 (AD, PERTH, MEL); Vivonne Bay, hill above jetty area (3559'49"S 137¹1'01"E), Lowrie 2825 \& Murfet, 7 Sep 2003 (AD, PERTH,

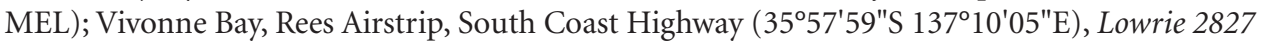
\& Murfet, 7 Sep 2003 (AD, PERTH, MEL); Birchmoor Road (3549'20"S 137²7'12"E), Lowrie 2829A \& Murfet, 7 Sep 2003 (AD, PERTH, MEL); Hog Bay Road, 14 km E of Kingscote turnoff $\left(35^{\circ} 46^{\prime} 21.0^{\prime \prime S} 137^{\circ} 37^{\prime} 33.4^{\prime \prime E}\right)$, Conran 1525, 28 Jun 2004 (AD, ADU); Corner of Halls Road and road to Kingscote, Kangaroo Island (3546'21.4"S, 137³7'34.2"E), 20 Jul 2006, Conran 1990 \& Duggan (AD, ADU); Playford Hwy, 22.5 km SW of Kingscote, Kangaroo Island (3546'21.4"S, 137³7'34.2"E), 20 Jul 2006, Conran 1991 \& Duggan (AD, ADU); 2 km W of Parndana on Playford Hwy, Kangaroo Island (3547'20.6"S, 137²1'00.0"E), 20 Jul 2006, Conran 1994 \& Duggan (AD, ADU); $2.5 \mathrm{~km} \mathrm{~W}$ of Gosse Richie Road turnoff, $27.5 \mathrm{~km} \mathrm{~W}$ of Parndana, Kangaroo Island (3547'49.3"S, 13657'04.3"E), 20 Jul 2006, Conran 1998 \& Duggan (AD, ADU); c. $9.5 \mathrm{~km} \mathrm{~N}$ of S Coast Hwy along Gosse Richie Road, Kangaroo Island (3554'02.3"S, 136 59'11.3"E), 20 Jul 2006, Conran $2000 \&$ Duggan (AD, ADU); 24.5 km NE of Vivonne Bay on S Coast Hwy, Kangaroo Island (35 51'25.6"S, 137²5'04.7"E), 20 Jul 2006, Conran $2003 \&$ Duggan (AD, ADU).

Drosera whittakeri Planch., Ann. Sci. Nat. ser. 3 9: 302 (1848)

Neotype here selected: South Australia: corner of Green Hill Road and Cemetery Road, Encounter Bay (3532'25"S 138³6'23"E), A. Lowrie 2835 \& D.E. Murfet, 8 Sept 2003 (neo: $\mathrm{AD}$, isoneo: PERTH, MEL, K, HL).

Illustrations: Lowrie (1998: 261); Lowrie (1998: 263, photos).

Perennial herb, solitary, tuberous, green, orange-yellow or red, with leafy rosette, $4-8 \mathrm{~cm}$ diam. Tuber orange, \pm globose, $c$. 6-10 mm long, c. 6-10 mm diam., depressed laterally, enclosed in a number of black papery sheaths at the end of a vertical subterranean stem 4-5 cm long. Leaves broadly spathulate, adpressed to the soil surface, with 6-15 leaves per rosette; petiole $15-35 \mathrm{~mm}$ long, $4.5-5.5 \mathrm{~mm}$ wide at base, dilated to $6.0-7.5 \mathrm{~mm}$ wide distally at base of lamina, longitudinally strongly 5-ridged, margin entire, glabrous; lamina obovate to broadly obovate, $10-15 \mathrm{~mm}$ long, $9-13 \mathrm{~mm}$ wide at anthesis, basal margin entire, distally dentate with apex dentate (more readily observed from abaxial surface), with glandular trichomes terminating each apical dentate marginal segment, insect-catching glands positioned on adaxial surface near margin of lamina with slightly shorter glands medially, trichomes green to translucent red with dark red glandular heads, abaxial lamina glabrous, veins branched towards apex (more readily observed in dried, blackened specimens). Inflorescence consisting of single flowers arising from the centre of the rosette, or sometimes terminal on a short $(<10 \mathrm{~mm})$ scape. Flowers up to 20 , pedicels \pm similar in colour to leaves, $3-6 \mathrm{~cm}$ long, sparsely covered with scattered sessile glands, pedicels \pm decumbent in fruit, prostrate or slightly arching. Sepals green to reddish, narrowly ovate-elliptic, 6-8 $\mathrm{mm}$ long, 3-4 $\mathrm{mm}$ wide, margins and apex entire, abaxial surface black dotted (more easily observed in dried specimens), with a small number of scattered minute sessile glands similar to those on scape, otherwise glabrous. Petals white, cuneate, margins entire, apex truncate-crenulate, $8-15 \mathrm{~mm}$ long, 6-10 mm wide. Stamens 5, 4-5 mm long, filaments white, anthers white, pollen pale yellow. Ovary green, obovoid, 2-2.3 mm long, 1.7-1.9 mm diam. Style-stigmas 3, white, 1.5-1.7 mm long, each divided into many filiform branching segments, glabrous, 
stigmatic portion white, dividing apically into 4, flat-topped, papillose segments. Seed charcoal black, angular, ovoid-cylindrical, 1-1.3 mm long, 0.7-1 mm diam., micropyle within indented basal pole, apical pole indented, surface sculpture irregularly hexagonal with weakly thickened anticlinal margins. (Figs $2 \mathrm{~d}$; 3 h,i). Chromosome number $2 n=28$ (Kondo \& Lavarack 1984).

Typification: Planchon (1848) cited two specimens in his treatment of Drosera whittakeri: "In Novae-Hollandiae ora meridionali ad Port-Phillips; Gunn no. 6 in herb. Hook. et ad Encounter-bay; Whittaker ibid." This collection was purchased by W.J. Hooker and is now housed at $\mathrm{K}$ (although apparently without the D. whittakeri and D. aberrans specimens). Because that citation includes elements from two species as defined here, D. whittakeri s. str. should be considered to be typified by the Whittaker collection "ad Encounter-bay; Whittaker ibid [in herb. Hook.]", as it represents material from South Australia within the range of D. whittakeri, whereas the specimen "In Novae-Hollandiae ora meridionali ad Port-Phillips; Gunn no. 6 in herb. Hook." is excluded as it represents material from Port Phillip Bay in Victoria, where only D. aberrans occurs. However, searches at K and BM have failed to locate any Whittaker or Gunn collections of D. whittakeri or related species. Because there are no collections referable to the original description, nor apparently any by either of those collectors from South Australia of this species, a neotype (Lowrie 2835 \& Murfet) has been designated from recent collections taken near Encounter Bay, near where Whittaker's original collections were made and where the species is still locally abundant.

Etymology: the epithet whittakeri honours Joseph Whittaker (1815-1894), a nurseryman from Breadsall, Derbyshire, England who collected c. 300 plant specimens from Adelaide and the southern Mount Lofty Ranges to Encounter Bay, South Australia from 1839-1840.

Habitat: common in a range of soil types from sand to clay-loams, rarely lateritic gravels, but not on limestone-derived clays. The plants grow in full sun or partial shade in open woodlands, heaths and grasslands.

Distribution: widespread through the Mount Lofty Ranges, South Australia as well as Kangaroo Island, with scattered collections from Yorke Peninsula (Fig. 1d). The species extends east in the Murrayland to the Coorong National Park and Monarto Conservation Park, where its range overlaps narrowly with $D$. aberrans, but with no obvious intermediates.

Conservation status: common and well represented in conservation areas. Not threatened.

Notes: the species flowers July-October and has a dry dormancy period as a subterranean tuber over summer. Leaf colour does not appear to be a function of exposure, as green-, orange-yellow- and red-leaved forms grow together at many sites, and continue to do so under uniform cultivation (Clayton 2003 and pers. obs. by both authors), although plants also tend to turn redder with age.

A larger, more-robust form of $D$. whittakeri has also been reported from the Adelaide Hills (Lowrie 1989, 1998; Clayton 2003) and often has many more flowers and semipendulous rather than prostrate fruits. Nevertheless, examination of populations across the species'range shows that there is gradual introgression between the forms, with no clear morphological or geographic boundaries. The robust plants often grow on relatively better soils (loams versus sands), often in association with Acacia paradoxa 
DC. (Mimosacaeae), and their size might reflect increased soil nitrogen under these shrubs. However, since they continue to grow larger than the type (coastal backdune) form in cultivation, they might best be considered an ecotype.

Selected specimens examined: South Australia: Mount Billy Conservation Park, Hindmarsh Tiers (3525'27"S 138 34'12"E), Lowrie 2802 \& Murfet, 5 Sept 2003 (AD, PERTH, MEL); Talisker

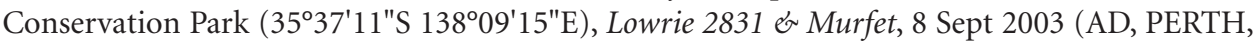
MEL); Beach-side heathland, Parsons Beach, Encounter Bay (3537'59"S 138²8'45"E), Lowrie 2834 \& Murfet, 8 Sept 2003 (AD, PERTH, MEL); Corner of Green Hill Road \& Cemetery Road, Encounter Bay (35³2'25"S 138³6'23"E), Lowrie 2835 \& Murfet, 8 Sept 2003 (AD, PERTH, MEL); Piggot Range Road, Southern Mount Lofty Ranges ( $35^{\circ} 08^{\prime} 09.2^{\prime \prime S} 138^{\circ} 35^{\prime} 13.1^{\prime \prime E}$, Conran 1972, 5 Jul 2006 (AD, ADU); Green Hill Road 350m N of road to Encounter Bay (35³2'05.3"S 138³6'09"E), Conran 1977, 5 Jul 2006 (AD, ADU); Playford Hwy, 22.5 km SW of Kingscote, Kangaroo Island (3546'21.4"S, 137³7'34.2"E), 20 Jul 2006, Conran 1992 \& Duggan (AD, ADU); 29 km W of Parndana on Playford Hwy opposite Flinders Chase National Park, Kangaroo Island (3547'32.6"S, 136 55'38.9"E), 20 Jul 2006, Conran 1996 \& Duggan (AD, ADU); $2.5 \mathrm{~km}$ W of Gosse Richie Road turnoff, $27.5 \mathrm{~km}$ W of Parndana, Kangaroo Island ( $35^{\circ} 47^{\prime} 49.3^{\prime \prime S}$, 136 57'04.3"E), 20 Jul 2006, Conran 1997 \& Duggan (AD, ADU); 4km S of Playford Hwy on Gosse Richie Road, Kangaroo Island (3549'39.2"S, 13658'44.0"E), 20 Jul 2006, Conran 1999 $\&$ Duggan (AD, ADU); c. $9.5 \mathrm{~km}$ N of S Coast Hwy along Gosse Richie Road, Kangaroo Island (3554'02.3"S, 136 59'11.3"E), 20 Jul 2006, Conran $2001 \&$ Duggan (AD, ADU); 21 km E of Gosse Richie Road turnoff along S Coast Hwy (35³9'02.4"S, 13707'38.4"E), 20 Jul 2006, Conran 2002

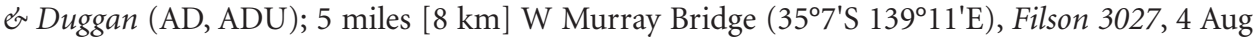
1960 (MEL37462A); Belair National Park ca 7 miles [11.2 km] SSE Adelaide (350'S 138 $\left.37^{\prime} \mathrm{E}\right)$, Filson 1658, 7 Sep 1958 (MEL37625A); Kalkaburg 15 miles [24 km] NW from Ardrossan (34 $16^{\prime} \mathrm{S}$ $\left.137^{\circ} 44^{\prime} \mathrm{E}\right)$, Tepper 761, Jan 1880 (MEL96940A); Near Mount Lofty (3458'S 138 $43^{\circ} \mathrm{E}$ ), Tepper s.n., 1884 (MEL96943A); Yorke Peninsula, Tepper s.n., no date (MEL96948A); North Cunningham

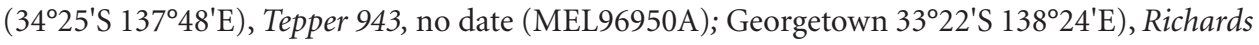
s.n., 1893 (MEL96956A); Newland Head Conservation Park (353'ㅇ 138³1'E), Murfet 1081b, 4 Aug 1991 (MEL715861A).

\section{Acknowledgments}

Erwin Schmutz is thanked for his collections, field observations and discussions on the new species. The directors of MEL and AD are thanked for access to collections and the South Australian Department of Environment and Heritage is thanked for permission to collect from lands under its control. Jeremy Bruhl as ABLO is thanked for searching $\mathrm{K}$ and $\mathrm{BM}$ for possible types or historically relevant collections of our species. Denzel Murfet (DM) and Chris Duggan are thanked for collections, field observations and companionship on trips with AL and JGC respectively. Bev and Dean Overton are thanked for Kangaroo Island observation data, local knowledge and hospitality while AL and DM were on Kangaroo Island. John Thompson and Robert Gassin are thanked for additional field observations in Victoria. 


\section{References}

Barker WR, Barker RM, Jessop J \& Vonow HP, Eds (2005) Census of South Australian Vascular Plants. 5th Edition. Journal of the Adelaide Botanic Gardens, Supplement 1. (Botanic Gardens of Adelaide \& State Herbarium: Adelaide)

Bates R (1991) Drosera praefolia Tepper: a species endemic to South Australia. Journal of the Adelaide Botanic Gardens 14: 99-102.

CHAH (2006) AVH: Australia's Virtual Herbarium. http://www.chah.gov.au/avh/

Chandler GE \& Andersson JW (1976) Studies on the nutrition of Drosera species with reference to the carnivorous habit. New Phytologist 76: 129-141.

Clayton C (2003) Carnivorous Plants on Kangaroo Island, South Australia: A Field Guide and Cultural notes to the Indigenous Species. (Published by the author: Dandenong)

Conran JG (2008) Aestivation organ structure in Drosera subgen. Ergaleium (Droseraceae): corms or tubers; roots or shoots? Australian Journal of Botany 56: 144-152.

Cooke RG \& Segal W (1950) Colouring matters of Australian plants. I. The structure of droserone. Australian Journal of Scientific Research 3: 628-634.

Gibson R (1995) Drosera praefolia. Carnivorous Plant Newsletter 24: 73-74.

Jeffrey DW (1967) Phosphate nutrition of Australian heath plants I. The importance of proteoid roots in Banksia (Proteaceae). Australian Journal of Botany 15: 403-411.

Kondo K \& Lavarack PS (1984) A cytotaxonomic study of some Australian species of Drosera L. (Droseraceae). Botanical Journal of the Linnean Society 88: 317-333.

Lowrie A (1987) Carnivorous Plants of Australia, vol. 1. (University of Western Australia Press: Perth)

Lowrie A (1989) A study of the Drosera whittakeri-like plants found in South Australia. Bulletin of the Australian Carnivorous Plant Society 8: 43-47.

Lowrie A (1998) Carnivorous Plants of Australia, vol. 3. (University of Western Australia Press: Perth)

Lowrie A \& Carlquist S (1992) Eight new taxa of Drosera from Australia. Phytologia 73: 98-116.

Marchant N, Aston HI \& George AS (1982) Droseraceae. Pp. 9-64 in George AS (ed.) Flora of Australia, vol. 8. (Government Printer: Canberra)

Marchant NG (1986) Droseraceae. Pp. 360-363 in Jessop JP \& Toelken HR (eds) Flora of South Australia. (South Australian Government Printer: Adelaide)

Mueller F (1879) The Native Plants of Victoria Succinctly Defined. Part I. (J. Ferres, Govt. Printer: Melbourne)

Pate JS \& Dixon KW (1982) Tuberous, Cormous and Bulbous Plants. (University of Western Australia Press: Nedlands)

Planchon JÉ (1848) Sur la familie des Droséracées. Annales des Sciences Naturelles Botanique séries 3. 9: 285-309.

Schlauer J (1996) A dichotomous key to the genus Drosera L. (Droseraceae). Carnivorous Plant Newsletter 25: 67-88.

Schlauer J (2006) World Carnivorous Plant List: Nomenclatural Synopsis of Carnivorous Phanerogamous Plants. (http://www.omnisterra.com/botany/cp/data/jans.db)

Shattuck SO (2003) Biolink Ver. 2.0.5 (CSIRO: Melbourne)

Tepper JGO (1892) Seltene und neue Südaustralische Pflanzen. Botanisches Centralblatt 50: 353-357.

Manuscript received 01 November 2007, accepted 01 August 2008 